\title{
Projektowanie uniwersalne - zagospodarowanie przestrzeni dla osób niepełnosprawnych
}

Architekt projektując nowe lub modernizując stare budynki powinien dążyć do tego by oprócz spełnienia wymogów estetycznych, czy też bezpieczeństwa obiekty użyteczności publicznej czy też obiekty mieszkaniowe były przede wszystkim dostępne dla każdego użytkownika. Przestrzeń, w której porusza się każdy człowiek powinna być kształtowana w taki sposób by zaspokajała jego potrzeby bez względu na jego możliwości fizyczne czy psychiczne. Planowanie dostępnej przestrzeni dla osób niepełnosprawnych wiąże się z pewną koncepcją, która nazywa się projektowanie uniwersalne. Jej celem jest zapewnienie każdej osobie dostęp do wszelkich obiektów w środowisku zurbanizowanym. Inspiracją do przeprowadzenia badań dotyczących planowania dostępności przestrzeni dla osób niepełnosprawnych było obejrzenie projektu inżynierskiego, który polegał na zaprojektowaniu akademika dla studentów Gdańskiego Uniwersytetu Medycznego. Wówczas zaczęłam się zastanawiać czy studenci architektury projektując budynki mieszkalne czy użyteczności publicznej uwzględniają potrzeby osób niepełnosprawnych oraz jaką posiadają wiedzę dotyczące tejże grupy. Chcąc zilustrować problem planowania dostępnej przestrzeni dla osób niepełnosprawnych postanowiłam przybliżyć koncepcję projektowania uniwersalnego, czyli zagospodarowania przestrzeni dla osób niepełnosprawnych.

Słowa kluczowe: niepełnosprawność, projektowanie uniwersalne, zagospodarowanie przestrzeni, architekt

\section{Universal design - landscape planning for people with disabilities}

Architect designing new buildings or modernising old ones should not only pursue meeting esthetics and safety requirements, but above all ensure that the facility or housing is available for all users. Space, within each human is moving should be designed in such a way that satisfy users' needs regardless of their physical and mental abilities. Designing space for disabled persons involves the concept called universal design. Its aim is to provide access for each person to all facilities in urban environment. The inspiration of conducting research on planning space availability for people with disabilities was seeing engineering design, which included designing the hall of residence of Gdańsk Medical University. Then, I began to wonder if architecture students take into consideration needs of disabled people while designing housing and public facilities and what knowledge they have in this field. In order to provide an illustration of designing space for people with disabilities, I have decided to present the concept of universal design that is space planning for disabled persons.

Keywords: disabilities, Universal design, landscape planning, architect 


\section{Wprowadzenie}

Przestrzeń, w której żyje każdy człowiek, powinna być kształtowana w taki sposób, by mogła zaspokoić potrzeby wszystkich ludzi. W architekturze istnieje koncepcja, która w zamyśle ma spełniać to zadanie, nazywana jest projektowaniem uniwersalnym. E. Kuryłowicz opisuje je jako „projektowanie uniwersalne dla wszystkich dotyczy po prostu projektowania, w którym uwzględnia się potrzeby wszystkich ludzi - użytkowników otoczenia, niezależnie od ich możliwości fizycznych i psychicznych" [Kuryłowicz 2005: 13]. Zatem głównym założeniem projektowania uniwersalnego jest planowanie dostępności $w$ taki sposób, by każdy użytkownik mógł samodzielnie funkcjonować $\mathrm{w}$ środowisku, w którym żyje.

Należy zwrócić uwagę, iż dla osoby sprawnie funkcjonującej ominięcie przeszkody nie sprawia żadnego problemu. Inaczej jest w przypadku osób niepełnosprawnych, a w szczególności w przypadku osób niewidomych, słabowidzących czy niepełnosprawnych ruchowo, którzy zazwyczaj potrzebują pomocy podczas przemieszczania się w różne miejsca. Jednym ze stereotypów jest uważanie osoby niepełnosprawnej jako bezradnej, bezsilnej istoty, która wymaga nieustającej opieki. Projektowanie uniwersalne zmierza ku temu, by obalić ten mit. Dzięki dostosowaniu przestrzeni do potrzeb niepełnosprawnych użytkowników osoby niewidome, słabowidzące czy poruszające się na wózku inwalidzkim będą mogły przemieszczać się bez ograniczeń, a przede wszystkim bez potrzeby korzystania z pomocy. Przestrzeń, która jest wolna od jakichkolwiek barier, pozwoli tym osobom stać się bardziej samodzielnymi. Im bardziej osoby niepełnosprawne są niezależne od innych, tym większa jest szansa na uzyskanie pełnej akceptacji ze strony środowiska, a wówczas osoby niepełnosprawne będą mogły stać się równoprawnymi uczestnikami życia społecznego.

\section{Planowanie dostępności dla osób niepełnosprawnych w świetle polskiego prawa}

Polska przystępując do Unii Europejskiej w 2004 r. podjęła automatycznie zobowiązanie, aby ustosunkować się do rozwiązań legislacyjnych obowiązujących na terenie Unii Europejskiej. Dotyczyło to również obszaru zmian w ramach polityki społecznej, prowadzonej wobec osób niepełnosprawnych [Szczupał 2013]. W Polsce istnieją dwa podstawowe akty prawne, które regulują proces budowlany, od podjęcia decyzji, a więc zaczynając od projektowania danego obiektu, do jego budowy. Są to „Ustawa Prawo budowlane” oraz „Rozporządzenie Ministra 
Infrastruktury w sprawie warunków technicznych, jakim powinny odpowiadać budynki i ich usytuowanie" [Kowalski 2011]. Na podstawie podstawowych akt, które obowiązują w naszym kraju, warto przyjrzeć się planowaniu dostępności dla osób niepełnosprawnych w świetle polskiego prawa - analizie poddane zostaną przykładowe akty prawne, które dotyczą planowania dostępności w budynkach mieszkalnych, obiektach handlowo-usługowych oraz w transporcie publicznym.

W rozporządzeniu Ministra Infrastruktury w sprawie warunków technicznych, jakim powinny odpowiadać budynki i ich usytuowanie, określającym parametry różnych pomieszczeń w budynkach wielorodzinnych, zostało zapisane, iż: „1. W budynku wielorodzinnym szerokość w świetle ścian pomieszczeń powinna wynosić co najmniej:

1) pokoju sypialnego przewidzianego dla jednej osoby $-2,2 \mathrm{~m}$,

2) pokoju sypialnego przewidzianego dla dwóch osób - 2,7 m,

3) kuchni w mieszkaniu jednopokojowym - 1,8 m,

4) kuchni w mieszkaniu wielopokojowym - 2,4 m.

2. W mieszkaniu co najmniej jeden pokój powinien mieć powierzchnię nie mniejszą niż 16 m²" (Dz. U. z 2002 r. Nr 75, poz. 690, art. 94).

Jak można zauważyć, podane parametry nie uwzględniają potrzeb osób poruszających się na wózku inwalidzkim. Minimalna wielkość tzw. wolnej przestrzeni, która umożliwia swobodne manewrowanie wózkiem inwalidzkim, wynosi $1,5 \times 1,5 \mathrm{~m}$.

W sytuacji ustawienia w pomieszczeniu niezbędnych mebli, podane wielkości mogą być niewystarczające dla osoby poruszającej się na wózku. Jedynym rozwiązaniem jest odpowiednia aranżacja pomieszczeń w taki sposób, by zapewnić beneficjentowi samodzielne przemieszczanie się po mieszkaniu [Kowalski 2011].

Kolejnym, ważnym elementem w budynkach wielorodzinnych, o którym należy wspomnieć, jest domofon. Niestety brakuje jakichkolwiek zapisów dotyczących ich usytuowania. Jednak według dotyczących standardów projektowania domofony powinny być umieszczone na wysokości 0,8-1,2 m. Ta wysokość jest odpowiednia dla osób poruszających się na wózku. Istotne jest także zachowanie wolnej przestrzeni, czyli 1,5x1,5m, która umożliwia manewrowanie wózkiem inwalidzkim. By domofony mogłyby być także użyteczne dla osób niewidomych, należy stosować tradycyjne modele, gdzie klawisze w klawiaturze są wypukłe. W przypadku instalacji elektrycznych, takich jak dzwonki do drzwi oraz włączniki światła optymalna wysokość powinna wynosić tyle samo co domofon - wysokość montażu wynosi 0,8-1,2 m [Kowalski 2011].

Kolejną grupą aktów prawnych, która została poddana analizie, były przepisy dotyczące obiektów handlowo-usługowych. Zgodnie z ideą projektowania uniwersalnego budynki, takie jak; szpitale, urzędy, kina sklepy itp., także powinny 
być dostępne dla osób niepełnosprawnych. Rozporządzenie Ministra Infrastruktury w sprawie warunków technicznych, jakim powinny odpowiadać budynki i ich usytuowanie, zwraca uwagę, iż: „,w budynku użyteczności publicznej pomieszczenia ogólnodostępne ze zróżnicowanym poziomem podłóg powinny być przystosowane do ruchu osób niepełnosprawnych" (Dz. U. z 2002 r. Nr 75, poz. 690, art. 74). W przypadku budynków, które zbudowane są z kilku pięter, każdy z tych poziomów należy zaadoptować do potrzeb beneficjentów o różnej niepełnosprawności. Zatem przestrzeń komunikacyjna powinna mieć szerokość nie mniejszą niż $1,5 \mathrm{~m}$. Wymiary te przysługują także przestrzeni pomiędzy półkami w sklepach. Istotne jest także rozmieszczenie ścieżek dotykowych, które ułatwią poruszanie się osobom niewidomym. Przestrzeń wokół centrum handlowego także musi być przyjazna dla niepełnosprawnych użytkowników. Dotyczy to m.in. miejsc parkingowych. W przypadku supermarketów i centrów handlowych miejsca parkingowe powinny być wyznaczone dla osób niepełnosprawnych. Powinny zajmować nie mniej niż 5\% miejsc parkingowych. Należy je umieścić w taki sposób, by zapewnić kierowcy możliwość przedostania się bezpośrednio na chodnik. W przypadku budynków usługowo-handlowych, które są niewielkie, liczba miejsc parkingowych zależy i wyłącznie do działu Zarządu Dróg Miejskich [Kowalski 2011].

Na zakończenie warto wspomnieć o aktach prawnych, które dotyczą planowaniu przestrzeni wokół komunikacji miejskiej. Dzięki dostępności do publicznych środków transportu osoba niepełnosprawna może być w pełni samodzielna, przemieszczając się bez problemu w różne miejsca. Jednak istotnym elementem jest zapewnienie bezpieczeństwa dla tychże osób, dlatego na przystankach tramwajowych, autobusowych czy na peronach powinny być tzn. strefy zagrożenia, które ułatwią przede wszystkich osobom słabowidzącym bądź niewidomym ocenić, gdzie zaczyna się krawędź przystanku. Strefa powinna być oznaczona pasem o szerokości 10 cm w żółtym kolorze [Kowalski 2011, za: Schwarz]. Dla osób niewidomych istotnym elementem są ścieżki dotykowe. Jednak w Polsce nie ma obowiązku prawnego stosowania ich na przystankach. Na przystankach tramwajowych czy autobusowych coraz częściej znajdują się elektroniczne tablice z rozkładami jazdy. Choć nie jest to dział, którym zajmują się architekci, jednak warto o tym wspomnieć, gdyż jest bardzo pomocny przede wszystkich dla osób z dysfunkcjami wzroku. Dzięki tym obiektom pasażerowie widzą dokładny czas przyjazdu oraz w którym kierunek jadą. Zaletą elektronicznych rozkładów jazdy jest możliwość zastosowania informacji głosowej, która jest zintegrowana z tablicami elektronicznymi. Jest to ogromna pomoc dla osób niewidomych [Kowalski 2011]. 


\section{Likwidacja barier w środowisku zurbanizowanym}

Bariery $\mathrm{w}$ środowisku zurbanizowanym są główną przyczyną wyłączania osób niepełnosprawnych z uczestnictwa w życiu społecznym. Ograniczają one dostęp do niektórych obiektów użyteczności publicznej i mieszkań. Utrudniają także osobom niepełnosprawnym swobodne przemieszczanie się. Architekci dzięki wiedzy na temat funkcjonowania osób niewidomych, słabowidzących i poruszających się na wózkach inwalidzkich powinni projektować tak przestrzeń, by umożliwić im czynny udział w życiu społecznym. Dlatego warto przyjrzeć się pewnym barierom, które z pewnością można zauważyć w środowisku zurbanizowanym. Według K. Jaranowskiej są to „bariery fizjograficzne, bariery techniczne, bariery organizacyjne" [Jaranowska 1996: 37].

Pokrótce zostanie omówiona bariera techniczna, gdyż ma ona największe znaczenie dla architektów podczas planowania dostępności dla osób niepełnosprawnych. Druga grupa barier, która została wymieniona przez K. Jaranowską, to wszelkiego rodzaju bariery techniczne, wśród których można wyodrębnić bariery architektoniczne, urbanistyczne i komunikacyjne [Jaranowska 1996].

Barierą architektoniczną są „utrudnienia dla osób niepełnosprawnych występujące w budynkach i ich elementach zewnętrznych, które ze względu na rozwiązania techniczne lub warunki użytkowania utrudniają lub uniemożliwiają swobodę ruchu osobom niepełnosprawnym" [Budny 2004: 13]. Przykładem bariery architektonicznej, jaką może napotkać osoba niepełnosprawna chcąc wejść do budynku, są drzwi wejściowe. Zazwyczaj są one zbyt wąskie dla osób jeżdżących na wózkach inwalidzkich lub dla niewidomych poruszających się $\mathrm{z}$ widzącym asystentem lub psem przewodnikiem. Korzystnym rozwiązaniem dla tych osób są przesuwane automatycznie drzwi. Natomiast szklane drzwi powinny być wyposażone w kontrastowe pasy, które mogą uchronić osoby słabowidzące przed zderzeniem się z nimi [Wysocki 2010]. Kolejnym elementem wyposażenia większości budynków są schody. Źle zaprojektowane mogą stać się barierą dla osób niepełnosprawnych, którzy pragną samodzielnie poruszać się po danym obiekcie. Zaleca się by tzw. bieg schodowy zawierał maksymalnie do 8 stopni. Każdy schodek musi mieć jednakową wysokość i głębokość. Wysokość stopnia powinna mieć $0,13 \mathrm{~m}$ natomiast głębokość zależy od jego wysokości. Gdy ciągi schodów są dłuższe, należy zaopatrzyć je w spoczniki, czyli w płyty, które oddzielą biegi schodowe. W obu przypadkach pierwszy i ostatni stopień musi być jaśniejszy od pozostałych. Kontrastowe oznakowanie pozwala osobom słabowidzącym zorientować się gdzie jest początek i koniec schodów. Schody także należy zaopatrzyć $\mathrm{w}$ poręcze również na spoczniku. W przypadku pierwszego, jak i ostatniego stopnia poręcze powinny być wydłużone o $0,3 \mathrm{~m}$. Takie rozwiąza- 
nie ułatwi osobom niepełnosprawnym swobodne poruszanie się. Obok schodów powinna także istnieć inna alternatywa w postaci pochylni.

Kolejnym rodzajem ograniczeń technicznych są bariery urbanistyczne, „czyli ograniczenia uniemożliwiające lub utrudniające osobom niepełnosprawnym dogodne warunki ruchu w obszarach zurbanizowanych" [Budny 2004: 13]. Istotną barierą urbanistyczną jest wszelkiego rodzaju nawierzchnia. Z jednej strony powinna odpowiadać charakterowi miejsca jednak z drugiej strony musi być dostosowana do potrzeb osób niepełnosprawnych. Zbyt gładkie powierzchnie mogą okazać się niebezpieczne, gdyż powodują poślizgnięcia. Dlatego asfalt, płyty betonowe lub kamienne są odpowiednimi surowcami do budowy chodników [Kuryłowicz 2005]. W tym momencie warto wspomnieć o ścieżkach dotykowych, które powinny być nieodłącznym elementem każdego chodnika. Faktury umieszczone na ciągach pieszych są wyczuwalne stopą bądź laską. Dzięki temu osoba niewidoma lub słabowidząca może bez problemu poruszać się $\mathrm{w}$ przestrzeni, zwłaszcza w otoczeniu, które nie jest dla niej znane [Wysocki 2010]. Niżej zostanie umieszczony schemat kombinacji faktur, który wyczuwalny jest stopą lub końcówką laski.

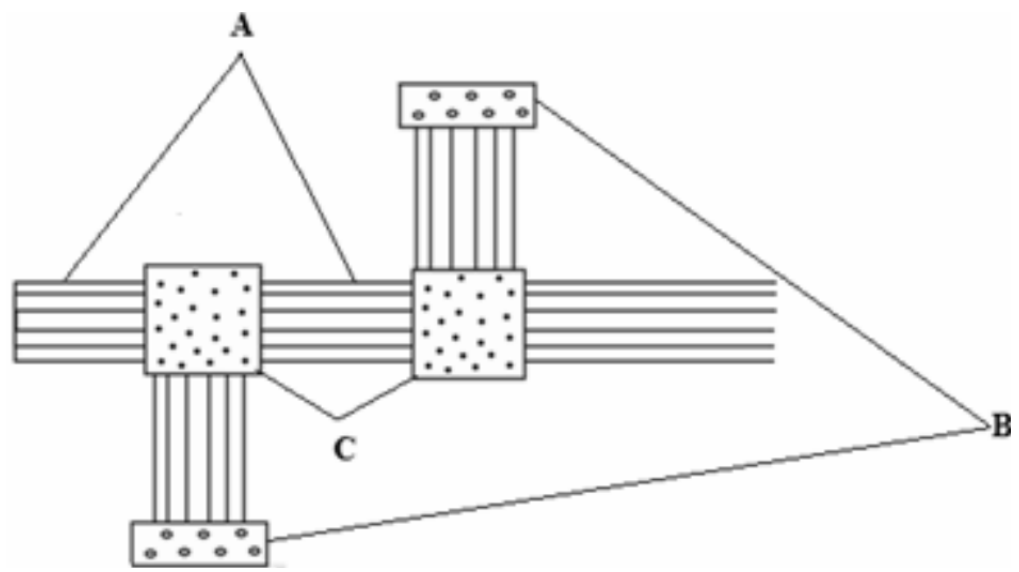

Rysunek 1. Kombinacja faktur wyczuwalna stopą bądź końcówką laski Źródło: [Kowalski 2014: 29].

Jak widać na zamieszczonym rysunku 1, kombinacja faktur dotykowych składa się z trzech elementów. Pierwsza z nich, która została oznaczona literą A, określana jest jako faktura kierunkowa. Jak sama nazwa wskazuje wyznacza ona kierunek ruchu. Kolejna, która została zaznaczona literą B, to faktura ostrzegawcza. Jej zadaniem jest ostrzegać osobę niewidomą lub słabowidzącą przed napotykaną przeszkodą. Trzecia z nich, oznaczona literą C, to faktura uwagi (informacji). Informuje ona o rozwidleniach dróg lub ich skrzyżowaniach [Kowalski 
2014]. Kolejnym, ważnym przykładem bariery urbanistycznej, która nie tylko utrudnia samodzielne przemieszczanie się po mieście, ale też może być poważnym zagrożeniem dla osób niewidomych lub słabowidzących, są ścieżki rowerowe. W Polsce powstaje ich coraz więcej dzięki aktywności środowiska rowerzystów. Często ścieżki powstają bezpośrednio już na istniejących chodnikach. Jedynie namalowana linia, znaki poziome lub pionowe rozdzielają ciągi pieszo-rowerowe. Niewyraźna granica stanowi realne prawdopodobieństwo potrącenia pieszego przez rowerzystę [Wysocki 2010]. Najlepszym rozwiązaniem jest oddzielenie ścieżek rowerowych. Dzięki temu niewidomi będą mogli bezpiecznie przemieszczać się po okolicy [Kuryłowicz 2005]. Jednak ta koncepcja może być trudna do wykonania ze względu na duże koszty budowy odrębnych dróg rowerowych [Wysocki 2010]. Jeśli taka inwestycja jest niemożliwa do zrealizowania, ścieżki pieszo-rowerowe muszą być wyraźnie oddzielone od siebie za pomocą m.in. zróżnicowanych faktur, balustrad, rzędem drzew lub też pasem trawnika. Takie rozwiązanie zapewni osobom niewidomym lub słabo widzącym bezpieczne przemieszczanie się po chodniku [Kuryłowicz 2005].

\section{Analiza badań własnych}

Na podstawie analizy literatury naukowej dotyczącej projektowania uniwersalnego za główny problem swoich badań przyjęłam postrzeganie projektowania uniwersalnego przez studentów architektury (pytanie badawcze: W jaki sposób studenci architektury postrzegają projektowanie uniwersalne czyli zagospodarowanie przestrzeni dla osób niepełnosprawnych?). By móc odpowiedzieć na to pytanie postawiłam także pytania szczegółowe. Oto one:

- Czym jest projektowanie uniwersalne dla studentów architektury?

- W jaki sposób studenci architektury postrzegają osoby niepełnosprawne?

- Czy podstawowe akty prawne, które regulują proces budowlany uwzględniają potrzeby osób niepełnosprawnych?

- Jakie bariery architektoniczne, które znajdują się w środowisku zurbanizowanym dostrzegają studenci architektury oraz w jaki sposób można je zlikwidować?

- W jaki sposób można zaaranżować mieszkanie by było ono dostępne dla osób słabowidzących?

- W jaki sposób można zaprojektować pomieszczenia takie jak: korytarz, łazienka, kuchnia czy sypialnia by było one dostępne dla osób niepełnosprawnych ruchowo a w szczególności dla osób poruszających się na wózku inwalidzkim?

W swoich badaniach posłużyłam się wywiadem jakościowym. W związku $\mathrm{z}$ tym $\mathrm{z}$ respondentami został przeprowadzony wywiad jakościowy (nieskate- 
goryzowany). Wywiad był jawny, przeprowadzony z pięcioma studentami architektury w przedziale wiekowym: 21-24 lat. Każdy z badanych studiuje na Politechnice Gdańskiej. Imiona respondentów zostały zmienione na potrzeby badań.

\section{Postrzeganie projektowania uniwersalnego przez studentów architektury}

W pierwszej części artykułu została poruszona kwestia projektowania uniwersalnego. Warto zastanowić się czym jest ono dla przyszłych młodych architektów. Dla pierwszej badanej, Weroniki projektowanie uniwersalne to:

Nie ma dla mnie architektury wspótczesnej bez projektowania uniwersalnego, czyli w momencie, kiedy już tworzymy nowe budynki one dla mnie musza być w petni przystosowane nie tylko dla osób niepetnosprawnych, ale również dla osób starszych czy osób, które po prostu maja problem poruszania się przestrzeni w sposób petny, w sposób petnosprawny, bo co z tego, że zrobimy tadna przestrzeń, tadny budynek jak nie każdy będzie mógł tam dotrzeć (...).

Weronika jako jedyna wśród osób badanych uważa, że współczesna architektura nie może istnieć bez projektowania uniwersalnego. Jest to bardzo istotna kwestia, ponieważ jest wiele zachwycających budynków, ale nie są one w pełni dostosowane do potrzeb każdego użytkownika. Samo projektowanie porównuje do zagadki sudoku, którą należy rozwiązać. To znaczy, że według Weroniki projektowanie uniwersalne:

narzuca kolejne jakby dla architekta, kolejne wytyczne, kolejne jakby no i niestety, ale i bariery i ogranicza nas troszeczkę, ale ogranicza nas, ale wymaga od nas więcej myślenia.

Jak słusznie zaznaczył też kolejny badany, Michał, projektowanie uniwersalne to pewnego rodzaju wyzwanie dla architekta. To wyzwanie zaczyna się już na etapie projektowym, gdzie architekci muszą tak przemyśleć, a później zaprojektować budynek, by sprostał on potrzebom wszystkich użytkowników. Analizując wypowiedzi respondentów zauważyłam, że wszyscy badani są zgodni, że architekci projektując budynki powinni myśleć o każdym użytkowniku. Jednak to pojęcie jest bardzo ogólne. Dlatego spytałam się moich respondentów, co mają na myśli, mówiąc: „o każdym użytkowniku”. Zaprezentuje według mnie najciekawszą wypowiedź, która mocno zapadła mi w pamięć. Według Michała projektowanie uniwersalne obejmuje:

Osoby z niepetnosprawnościq ruchowa, intelektualna, osoby poruszające się na wózkach czy może o kulach, osoby petnosprawne, osoby z jakimiś kontuzjami, osoby, które regularnie korzystają z jakiś obiektów i nie wiem, nie mają żadnych trudności z poruszaniem, osoby sporadycznie, które są tymczasowo itp. 
Michał uważa podobnie jak inne osoby badane, że architekt projektując budynki powinien zwrócić uwagę na potrzeby osób niepełnosprawnych, jak i pełnosprawnych. Słusznie zaznaczyl, że osoba pod wpływem doznanej kontuzji może także mieć trudności w przemieszczaniu się. Zatem architekt projektując budynki musi myśleć przyszłościowo. To znaczy powinien przewidzieć każdą ewentualność, każdą przeszkodę, jaką może napotkać nawet osoba w pełni sprawna.

\section{Główne zasady projektowania uniwersalnego według studentów architektury}

W literaturze istnieje siedem zasad projektowania uniwersalnego. Można powiedzieć, że te zasady są tzw. drogowskazem dla architekta, które mają mu pomóc w projektowaniu budynków by były one dostępne dla każdego użytkownika. Oto one:

„1. Użyteczność dla osób o różnej sprawności

2. Elastyczność w użytkowaniu

3. Proste i intuicyjne użytkowanie

4. Czytelna informacja

5. Tolerancja na błędy

6. Wygodne użytkowanie bez wysiłku

7. Wielkość i przestrzeń odpowiednie do dostępu i użytkowania" [Wysocki 2010: 21].

Jak można zauważyć, koncentrowały się głównie na swobodnym dostępie do budynków, przestrzeni publicznych i różnych technologii informacyjno-komunikacyjnych [Wysocki 2010]. Z wypowiedzi respondentów można stworzyć siedem zasad projektowania uniwersalnego, które pokazują, w jaki sposób należy projektować środowisko zurbanizowane by było pozbawione jakichkolwiek barier. Oto one:

1. Zdobycie odpowiedniej wiedzy

2. Współpraca z innymi specjalistami

3. Kontakt z osobami niepełnosprawnymi

4. Dostępna i czytelna przestrzeń

5. Przestrzeń pozbawiona jakichkolwiek barier

6. Staranie zaprojektowane budynki

7. Troska o wszystkich użytkowników.

Jak można zauważyć, zasady, które stworzyli studenci architektury, są powiązane z tym co przedstawia literatura. Jednak bardziej koncentrowały się na zdobyciu odpowiedniej wiedzy przez studentów oraz wsłuchanie się w potrzeby 
osób niepełnosprawnych. Dzięki temu architekci będą mogli tworzyć projekty, które będą pozbawione jakichkolwiek barier.

\section{Wiedza studentów architektury dotycząca osób niepełnosprawnych}

Według Światowej Organizacji Zdrowia (WHO) niepełnosprawność to „wszelkie ograniczenia lub brak - wynikający z uszkodzenia - możliwości wykonywania czynności na poziomie uważanym za normalny dla człowieka" [Wapiennik, Piotrowicz 2002: 22]. Przez wiele lat właśnie w taki sposób definiowano pojęcie niepełnosprawności. Osoba niepełnosprawna miała podlegać selektywnej opiece społecznej i zdrowotnej. Model medyczny zwracał szczególną uwagę na różne defekty, różnice i odchylenia od norm. $Z$ biegiem lat zaczęto inaczej patrzeć na zjawisko niepełnosprawności. Osoby niepełnosprawne zaczęły stawać się pełnoprawnymi uczestnikami życia społecznego, obywatelami, którzy mają te same prawa co ludzie sprawni [Krause 2010]. Zatem niepełnosprawność nie jest już uważana za problem jednostki, ale całego społeczeństwa [Bujnowska 2009]. Dla projektowania uniwersalnego model społeczny odgrywa istotne znaczenie, gdyż aktywność niepełnosprawnego użytkownika uzależniona jest nie tylko od indywidualnych predyspozycji psychofizycznych danej jednostki. Ważną rolę odgrywa także tolerancja społeczna, dostępność środowiska fizycznego oraz przepisy prawne, które mają ułatwić niepełnosprawnym uczestnictwo w życiu społecznym [Wysocki 2010].

Przeprowadzając badania byłam ciekawa wypowiedzi respondentów dotyczących osób niepełnosprawnych. Chciałam się dowiedzieć, w jaki sposób są one postrzegane: czy pod pryzmat modelu medycznego czy społecznego. Zacytuję według mnie najciekawsze stwierdzenia. Według jednej z badanych, Agaty, niepełnosprawność jest po prostu pewną cechą, z którą człowiek przychodzi na świat. Agata posłużyła się nietypowym przykładem. Człowiek może urodzić się z pewnymi chorobami, alergiami. Nikt z nas nie ma na to wpływu, one po prostu są. Tak samo jest z niepełnosprawnością. Po prostu trzeba nauczyć się z tym żyć. Możliwe, że jej spostrzeżenia wynikają z faktu, iż rzadko miała kontakt z osobami niepełnosprawnymi. Jednak jej opinia dotycząca niepełnosprawności nie ma wydźwięku negatywnego.

Inne zdanie na ten temat ma Michał. Uważa, że to ludzie pełnosprawni definiują pojęcie niepełnosprawności. To oni decydują, który stan człowieka według nich odbiega już od normy. Respondent podzielił też niepełnosprawność na tymczasową lub na całe życie. Za tymczasową niepełnosprawność uważa nadwagę lub wylew. Czyli według niego jest to stan, który ogranicza daną osobę, która 
sprawia, że nie czuje się ona komfortowo we własnym ciele jak i w społeczeństwie.

Podane wypowiedzi dotyczyły samego pojęcia niepełnosprawności. Jak słusznie zauważył Łukasz:

niepetnosprawność to jest pojęcie a osoba niepetnosprawna to jest osoba. (...) Osoba niepetnosprawna jest zwiąana z niepetnosprawnościa, czyli jakby definiuję niepetnosprawność.

Warto bliżej przyjrzeć się wypowiedziom respondentów podejmujących próbę odpowiedzi na pytanie: kim jest osoba niepełnosprawna.

Agata uważa, że jest to

osoba jak osoba. Zwraca moja uwagę, gdy widzę kogoś na wózku inwalidzkim, albo niewidomego z laska, bo nie jest to codzienny widok, ale to tyle.

Według mnie jest to po raz kolejny najciekawsze sformułowanie jakie usłyszałam. Jest ono bardzo krótkie, ale przy tym rzeczowe. Z jej wypowiedzi mogę wnioskować, że Agata na równi traktuje osoby niepełnosprawne z osobami pełnosprawnymi. Jedynie osoby niepełnosprawne wyróżniają się na tle innych tylko tym, że jeżdżą na wózku inwalidzkim albo poruszają się za pomocą laski.

Ciekawe spostrzeżenia dotyczące osoby niepełnosprawnej ma Łukasz:

No to jest osoba, która nie potrafi się poruszać samodzielnie, w takim tradycyjnym budowaniu, bez uwzględnienia projektowania uniwersalnego i wtaśnie używajac projektowania uniwersalnego umożliwiamy poruszać się samodzielnie, tak funkcjonować samodzielnie w budynku albo po terenie budynku...

Łukasz definiuje osobę niepełnosprawną z perspektywy architekta. Jest to bardzo ciekawe, gdyż pokazuje to, że specjaliści z różnych dziedzin mogą spostrzegać niepełnosprawność z różnych punktów widzenia uzależnionych od doświadczeń (np. zawodowych). Przykładem są pedagodzy specjalni i architekci. Ci pierwszy skupiają uwagę na edukacji osób niepełnosprawnych, natomiast architekci zwracają uwagę na samodzielność w poruszaniu się w budynkach. Jednak obie te grupy mają wspólny cel. Mianowicie pomóc osobom z niepełnosprawnościami w byciu jak najbardziej samodzielnymi w otaczającym środowisku.

\section{Planowanie dostępności dla osób niepełnosprawnych w świetle polskiego prawa}

Jedną z kwestii, która interesowała mnie podczas konstruowania projektu badawczego, było sprawdzenie czy podstawowe akty prawne, które regulują proces budowlany, uwzględniają potrzeby osób niepełnosprawnych. Analizując mate- 
riały źródłowe zauważyłam, że niestety akty prawne obowiązujące w Polsce, dotyczące dostępności przestrzeni dla osób niepełnosprawnych, są dosyć ogólne. Istnieje także wiele nieścisłości, które mogą przyczynić się do powstawania barier $\mathrm{w}$ środowisku zurbanizowanym.

Zdania badanych studentów architektury dotyczące tej kwestii są podzielone, a ich wiedza dotycząca planowania dostępności okazała się bardzo ogólna. Podczas badań wymieniali kilka parametrów, jakie powinny być zachowane przy projektowaniu budynków. Najczęściej były to wymiary, które dotyczą wolnej przestrzeni manewrowej wózka inwalidzkiego - 1,5x1,5 m, szerokość drzwi-0,9 m oraz szerokość korytarzy $-0,9 \mathrm{~m}$. Wypowiedzi respondentów były bardzo ciekawe, dlatego zdecydowałam się przytoczyć ich wypowiedzi na temat planowania dostępności dla osób niepełnosprawnych w świetle polskiego prawa. Według Weroniki polskie prawo uwzględnia potrzeby osób niepełnosprawnych. Zaznacza także, że osoby niepełnosprawne nie są jedyną grupą użytkowników, na którą trzeba zwrócić uwagę podczas projektowania przestrzeni, więc tak naprawdę nie da się wszystkich zadowolić. Poza tym polskie prawo nie powinno ograniczać architekta, bo przecież jedną z zasad projektowania uniwersalnego jest podchodzenie do beneficjenta w sposób indywidualny.

Agata, kolejna osoba badana, miała odmienne zdanie dotyczące uwzględniania potrzeb osób niepełnosprawnych przez polskie prawo. Jej postawa dotycząca systemów prawnych jest neutralna. Nie zaprzecza, ani nie neguje faktu, że tak naprawdę polskie prawo nie bierze pod uwagę potrzeb osób niepełnosprawnych. Przyczyną jej postawy jest to, że Agata uważa swoją wiedzę za niewystarczającą. Jest to bardzo dojrzałe zachowanie.

Kolejna wypowiedź dotycząca uwzględnienia potrzeb osób niepełnosprawnych przez polskie prawo należy do Michała. Zauważa on, że polskie prawo dotyczące planowania dostępności dla osób niepełnosprawnych posiada pewne nieścisłości. Jest on zdania, że projektując budynki nie można kierować się tylko wytycznymi, które zostały ustanowione przez polskie prawo. Według niego liczy się przede wszystkim zdrowy rozsądek.

Następna respondentka, Patrycja, uważa, że polskie prawo jest mało sprecyzowane. Jest tego samego zdania co autorzy różnych publikacji, którzy twierdzą że polskie systemy prawne dotyczące planowania dostępności dla osób niepełnosprawnych są mało sprecyzowane. $\mathrm{W}$ dodatku nie ma konkretnych wymogów, które piszą, że należy stosować podane parametry. By usunąć pewne niejasności warto rozwinąć, uszczegółowić pewne rozporządzenia, które na pewno ułatwiłyby pracę architektów.

Na koniec przytoczę moim zdaniem najciekawszą wypowiedź dotyczącą planowania dostępności dla osób niepełnosprawnych w świetle polskiego prawa. 
Wydaje mi się, że ostatnio czytałem taka publikację pana Marka Wysockiego. Czytałem, byt w magazynie "Murator Achitektura". Byt taki dodatek projektowanie dla osób niepetnosprawnych i właśnie tam Pan Marek Wysocki się wypowiadat, że jest dużo niedociagnięć w prawie budowlanym, że dużo jest rzeczy nie branych pod uwage i ja w sumie... Ja mu wierzę. Wydaje mi się, że gdyby byty naprawdę mocne warunki stawiane architektom to my bylibyśmy już uczeni tego na studiach, robiąc te projekty, bo wątpię, że tutaj nikt by nam na ten temat nie mówił, jeżeli to by było naprawdę ważne. Więc myślę, że nie jest tak dobrze z tym naszym prawem co do osób niepetnosprawnych.

Ta wypowiedź pokazuje jak naprawdę wygląda planowanie dostępności dla osób niepełnosprawnych. W dodatku Łukasz powołuje się na profesora Marka Wysockiego, który jest ekspertem w dziedzinie projektowania uniwersalnego. Respondent słusznie też zauważa, że gdyby polskie prawo było dobrze sprecyzowane oraz gdyby zaczęto uczyć przyszłych architektów jak należy projektować przestrzeń, by była ona przyjazna dla osób niepełnosprawnych, to nie powstalyby bariery w środowisku zurbanizowanym.

\section{Likwidacja barier w środowisku zurbanizowanym}

Przypomnę, iż w środowisku zurbanizowanym istnieją trzy główne bariery, które z pewnością utrudniają osobom niepełnosprawnym swobodne przemieszczanie się. Według K. Jaranowskiej są to:

- „bariery fizjograficzne (jest to jedyna z barier nie została utworzona przez człowieka tylko za pomocą środowiska naturalnego),

- bariery techniczne ( $w$ tym architektoniczne, urbanistyczne i komunikacyjne),

- bariery organizacyjne" (np.: roboty drogowe, źle odśnieżone chodniki, dziury w nawierzchni) [Jaranowska 1996: 37].

$\mathrm{Z}$ racji, iż materiał zebrany podczas badań jest bardzo obszerny, przytoczę wypowiedzi respondentów, które dotyczą barier architektonicznych.

Pierwszą barierą architektoniczną są schody. Choć tą przeszkodę osoby niepełnosprawne mogą napotkać w budynku, jak i w obszarze zabudowanym postanowiłam zaklasyfikować te ograniczenie do barier architektonicznych. Tak więc, jak trafnie zaznaczyła Weronika, schody mogą stać się wielką przeszkodą do pokonania. Zwłaszcza podjazdy, które mają pomóc osobom poruszającym się na wózku, a tak naprawdę stają się ogromną barierą nie do przejścia. Ja również miałam okazję obejrzeć film, w którym kaskader próbował zjechać ze stromej pochylni. Za każdym razem kończyło się to upadkiem. Michał dostrzegł jeszcze jedną przeszkodę, która może utrudnić w wchodzeniu po schodach. Brak poręczy może być utrudnieniem nie tylko dla osób niewidzących czy słabowidzących. Dla osób z niepełnosprawnością ruchową, które poruszają się za pomocą kul, 
także może być to dużym ograniczeniem. By schody mogły być dostępne dla osób niepełnosprawnych należy zamontować pochylnię o odpowiednim kącie nachylenia. $\mathrm{W}$ dodatku jak słusznie zaznaczyła też Weronika:

jak sa biate schody to powiedzmy powinno być szary pasek żeby osoba niedowidzaca zauważyła, że idzie po schodach (...).

W przypadku oznakowania schodów najczęstszym kolorem, jaki jest stosowany to żółty. Jednak po prostu ważne jest stosowanie kontrastów.

Kolejną barierą architektoniczną, którą wymienili respondenci były wąskie przestrzenie do tego by tam manewrować wózkiem (...). A więc architekci projektując budynki często zapominają o tak zwanej wolnej przestrzeni. Najczęstszą barierą architektoniczną jest też źle zaprojektowana łazienka. Jak słusznie zauważyła Patrycja:

Brak jakichś uchwytów, które moga utatwić, no to też jest bardzo dużo btędów. No takich na przykład, że podjeżdża osoba na wózku do umywalki i nie może do końca podjechać tylko zahacza o wszystko co się tam pod umywalką dzieję albo lustro jest jakoś za wysoko powieszone i nie może się przejrzeć normalnie. Jakby na przykład przy toalecie jest sptuczka, ze musi się wygią́ po prostu totalnie za plecami i no też jest takie straszne.

Wypowiedź Patrycji pokazuje jak wiele ograniczeń można napotkać w jednym pomieszczeniu. Jest tyle detali, na które powinien zwrócić uwagę architekt projektując chociażby łazienkę by była ona przystosowana do potrzeb osób niepełnosprawnych. Ciekawym rozwiązaniem na likwidację barier architektonicznych przedstawiła Patrycja:

Po prostu nie projektować dla siebie jako swojej wizytówki, swojej marki i wyłacznie, ale też projektować po prostu dla ludzi, projektować dla innych. budynek nie powinien być taka pięknym wizerunkiem architekta tylko czymś więcej, takim, że budynek, każdego tak jakby zaprasza.

Dlatego tak bardzo ważne jest by architekci przestrzegali zasady projektowania uniwersalnego.

\section{Aranżacja mieszkań dla osób słabowidzących}

W części teoretycznej pokrótce opisałam rozwiązania, jakie zaproponował K. Kowalski, planując dostępną przestrzeń w budynkach mieszkalnych dla osób słabowidzących. Prowadząc badania chciałam się dowiedzieć, jaka jest aktualna wiedza studentów architektury dotycząca aranżacji mieszkań dla tejże grupy osób. Przedstawię najciekawsze propozycje aranżacji mieszkań dla osób słabowidzących. 
Patrycja uważa, że budynki mieszkalne, które mają być dostosowane do potrzeb osób słabowidzących, nie powinny mieć żadnych progów. To z pewnością ułatwi swobodne przemieszczanie się po mieszkaniu. Przestrzeń powinna być intuicyjnie łatwa do poruszania. Jednak Patrycja nie wytłumaczyła dokładnie, co ma na myśli proponując to rozwiązanie. Dopiero Łukasz wyjaśnil, że jest to po prostu zminimalizowanie przeszkód. Respondentka dodaje jeszcze, że warto oznaczyć ważne miejsca kolorem żółtym, by osoba słabowidząca bez problemu mogła do nich dotrzeć. Na przykład można oznaczyć włączniki czy gniazdka. Dzięki temu beneficjent będzie mógł z łatwością włączyć światło bądź w sposób bezpieczny podłączyć ładowarkę do telefonu. Jak wspomniała Patrycja, oznaczenia powinno stosować się kolorem żółtym, gdyż jest to kolor, który widzi się jako ostatni. Dlatego ścieżki dotykowe, poręcze w komunikacji miejskiej czy przyciski otwierające drzwi w SKM mają właśnie taki kolor. Natomiast Michał zwrócił uwagę na dobrze usytuowanie lamp oraz wykorzystanie naturalnego i sztucznego oświetlenia podczas aranżacji mieszkań. Zaznaczył też, że warto umieścić różne faktury, które pozwolą odróżnić jedno pomieszczenie od drugiego. Istotne jest także zastosowanie różnych kontrastujących barw we wnętrzu. Respondent podał także rozwiązania, które żaden z poprzednich badanych nie wymienił. Według niego dobrym pomysłem jest stosowanie drzwi rozsuwanych. Są one łatwiejsze w użyciu niż te otwierane wahadłowo klasycznie. Ciekawą sugestią jest zamontowanie systemów głośno mówiących, które informowałyby na przykład o nie zamkniętych drzwiach czy też może o temperaturze, która jest w środku pomieszczenia jak i na zewnątrz.

\section{Planowanie dostępności przestrzeni w budynkach mieszkalnych dla osób niepełnosprawnych ruchowo}

W części teoretycznej zostały przedstawione rozwiązania dotyczące planowania dostępności przestrzeni w budynkach mieszkalnych dla osób niepełnosprawnych ruchowo, a w szczególności dla osób jeżdżących na wózku inwalidzkim. Analizie zostały poddane pomieszczenia, takie jak: korytarz, łazienka, kuchnia, sypialnia. Prowadząc badania chciałam się dowiedzieć, w jaki sposób studenci architektury dostosowaliby wyżej wymienione pomieszczenia, tak by sprostały one potrzebom tychże osób. Ze względu na obszerną treść materiały przedstawię najciekawsze wypowiedzi.

Na początku przedstawię wypowiedzi dotyczące projektowania korytarzy. Łukasz zauważył, że te parametry szerokości korytarzy mogą różnić się od tego jak on wygląda, czy jest on bardziej podłużny, czy może na planie kwadratu. Tak 
więc z jego wypowiedzi wynika, że architekci projektując pomieszczenia powinny być elastyczni i podchodzić do każdego użytkownika indywidualnie. Dlatego podane wymiary są umowne i nie tylko są zależne od niepełnosprawnego beneficjenta, ale też od przestrzeni, którą architekt musi zagospodarować.

Następne pomieszczenie, które zostało poddane analizie, to łazienka. Według Weroniki prysznic nie powinien mieć żadnych progów. Uważa, że najlepszym rozwiązaniem jest montaż zasłonki. Respondenta twierdzi, że można zainstalować wannę pod jednym warunkiem, musi być dostosowana dla osób jeżdżących na wózku. Dlatego powinno się zamontować drzwiczki bądź drabinkę, która ułatwi wejście.

Kolejna wypowiedź dotyczy projektowania kuchni. Agata podała bardzo ciekawe rozwiązanie, by zwiększyć przestrzeń manewrową. Mianowicie, blaty powinny być wysuwane. $\mathrm{W}$ ten sposób beneficjent będzie mógł bez problemu podjechać wózkiem i swobodnie przy nim pracować. Dla niej blat zaprojektowany dla osoby niepełnosprawnej może nie być funkcjonalny dla osoby pełnosprawnej. Dlatego Michał zaproponował rozwiązanie, które ma ułatwić obu domownikom korzystanie z niego. Po prostu zaprojektować dwa blaty o różnej wysokości. Podany przykład pokazuje jak bardzo ważne jest podchodzenie do każdego użytkownika w sposób indywidualny. Agata dodała też, że szafki należy zamontować nisko, co ułatwi swobodne funkcjonowanie osoby poruszającej się na wózku.

Ostatnie wypowiedzi dotyczyły projektowania sypialni. Agata zwróciła uwagę na zachowanie przestrzeni manewrowej. Zaznaczyła też, że szafy powinny być nisko, tak by osoba poruszająca się na wózku mogła bez problemu sięgnąć po ubrania. Okna nie tylko w sypialni, ale też i w każdym innym pomieszczeniu powinny być zamontowane na odpowiedniej wysokości, by beneficjent bez żadnego problemu mógł je otworzyć czy też zamknąć. Według niej odpowiednia szerokość drzwi wynosi $90 \mathrm{~cm}$. Montaż odpowiedniej liczby lamp oraz zdalnie sterowanych rolet z pewnością ułatwiłyby swobodne funkcjonowanie w sypialni.

Natomiast Weronika zwróciła uwagę na bardzo istotną rzecz. Natomiast według niej istotną i jedyną kwestią w planowaniu przestrzeni sypialni dla osoby jeżdżącej na wózku jest usunięcie jakichkolwiek progów. Uważa, że osoba niepełnosprawna ruchowo sama zagospodarowuje sobie to pomieszczenie. Nie należy jej traktować jako bezradną istotę. Owszem potrzebuje większej opieki, ale to w niektórych czynnościach. Dlatego Weronika zaznaczyła, że planując przestrzeń w budynkach mieszkalnych należy skupić się: (...) żeby tam kuchnia, tazienka i wiadomo żeby drzwi byly minimum $90 \mathrm{~cm}$, żeby korytarz, żeby się zmieścit wózek. 


\section{Wnioski}

W punktach przedstawię najważniejsze treści, które podsumowują analizę moich badań:

1. Młodzi architekci, by zrozumieć czym jest projektowanie uniwersalne, powinni zaangażować się w różne inicjatywy, takie jak: branie udział w przeróżnych projektach, konferencjach, warsztatach bądź uczęszczać na dodatkowe zajęcia, które pokazują jakie potrzeby mogą mieć niepełnosprawni użytkownicy.

2. Studenci architektury uważają, że projektowanie uniwersalne jest przede wszystkim wielkim wyzwaniem dla architekta, ponieważ ma za zadanie nie dyskryminować żadnego użytkownika. Architekt musi także wsłuchiwać się w potrzeby każdej osoby, to znaczy być otwartym na opinie, uwagi osób niepełnosprawnych, jak i pełnosprawnych, co czasem nie jest wcale takie łatwe.

3. Główną zasadą projektowania uniwersalnego, jakie stworzyli studenci architektury, to zdobycie odpowiedniej wiedzy dotyczącej osób niepełnosprawnych. Istotną kwestią jest także: współpraca z innymi specjalistami, kontakt z osobami niepełnosprawnymi, zaprojektowanie dostępnej i czytelnej przestrzeń, która jest pozbawiona jakichkolwiek barier, staranie zaprojektowane budynki oraz troska o wszystkich użytkowników.

4. Studenci architektury twierdzą, że niepełnosprawność jest to nabyta lub wrodzona cecha, problem, stan, ograniczenie z którym muszą się zmagać nie tylko oni, ale też i całe społeczeństwo.

5. Wszyscy respondenci postrzegają osoby niepełnosprawne jako pełnoprawnych członków społeczeństwa, czyli patrzą na niepełnosprawność i na osoby niepełnosprawne pod kątem modelu społecznego. Ważne jest też, że architekci dzięki projektowaniu uniwersalnemu przyczyniają się do zwiększenia niezależności wśród osób niepełnosprawnych.

6. Studenci architektury potrafią sobie uzmysłowić, jakie trudności mogą napotykać w życiu codziennych osoby niepełnosprawne.

7. Badani nie posiadają dużej wiedzy dotyczącej dostępności przestrzeni dla osób niepełnosprawnych w systemach prawnych. Świadczą o tym nie tylko ogólne stwierdzenia, ale także fakt, że uwzględniali potrzeby tylko osób niepełnosprawnych ruchowo, a w szczególności osób, które poruszają się na wózku inwalidzkim.

8. Ich opinie dotyczące planowania dostępności dla osób niepełnosprawnych w świetle polskiego prawa są podzielone. Tylko dwóch studentów uważa podobnie jak autorzy różnych publikacji, że polskie prawo jest mało sprecyzowane i należy je skonkretyzować, a przede wszystkich architekci powinni je przestrzegać. 
9. Każdy z respondentów potrafi dostrzec bariery w środowisku zurbanizowanym. Jednak troje z nich opisało bariery fizjograficzne. Natomiast tylko jeden spośród pięciu badanych wymienił barierę organizacyjną. Najwięcej przykładów podali opisując ograniczenia techniczne, a przede wszystkim architektoniczne.

10. Badani podali rozwiązania, które mogłyby zmniejszyć bądź zniwelować bariery w środowisku zurbanizowanym. Przede wszystkim dotyczyły one zmiany prawa, które reguluje proces budowlany, a ściślej mówiąc sprecyzowanie go oraz konsekwentne stawianie wymogów architektom, by je przestrzegali. Istotną kwestią jest też zdobycie wiedzy na temat projektowania uniwersalnego oraz organizowanie spotkań z udziałem osób niepełnosprawnych, które wskazałyby, w jaki sposób projektować budynki, by uwzględniały ich potrzeby.

11. Pomysły, które zaprezentowali studenci architektury dotyczące planowania przestrzeni w budynkach mieszkalnych dla osób słabowidzących, są zbieżne z tymi, które zostały zaprezentowane w literaturze. Oprócz tego respondenci wymienili też całkiem nowe rozwiązania, takie jak: stosowanie kontrastów i faktur w różnych pomieszczeniach, oznaczenie pierwszego i ostatniego stopnia na schodach, przymocowanie odpowiednich rodzajów grzejników czy też zamontowanie urządzeń, które z pewnością ułatwią funkcjonowanie osób z dysfunkcjami wzroku w budynku mieszkalnym.

12. Wiedza studentów architektury dotycząca planowania przestrzeni w budynkach mieszkalnych dla osób poruszających się na wózku jest duża. Jest jednak ogólna, ponieważ nie podają konkretnych schematów na zaprojektowanie danych pomieszczeń, bo każdego beneficjenta chcą traktować indywidualnie.

\section{Zakończenie}

Ogólna wiedza studentów architektury, dotycząca planowania przestrzeni dla osób niepełnosprawnych, spowodowana jest tym, że w trakcie studiów bardzo mało mówi się o planowaniu dostępności. W dodatku wykładowcy nie przywiązują wagi, by projekty studentów architektury były dostępne dla każdego użytkownika. By zlikwidować bariery w środowisku zurbanizowanym wykładowcy powinni wdrążać idee projektowania uniwersalnego. Aby studenci architektury mogli poszerzyć wiedzę z tego zakresu, warto organizować spotkania z udziałem osób niepełnosprawnych, które mówiłyby, w jaki sposób należy projektować budynki czy przestrzeń publiczną, które uwzględniały ich potrzeby. Ciekawym rozwiązaniem jest rozpowszechnianie takich projektów, jak: „Miasto bez barier" czy wszelakich konferencji, które poruszają tematykę projektowania uniwersalnego. Istotną kwestią jest także zmiana prawa, która reguluje proces budo- 
wlany, a ściślej mówiąc sprecyzowanie aktów prawnych oraz konsekwentne stawianie wymogów architektom, by je przestrzegali. Dzięki tym rozwiązaniom środowisko zurbanizowane będzie dostępne pod każdym względem dla osób niepełnosprawnych.

\section{Bibliografia}

Bujnowska A. (2009), Uwarunkowania postaw studentów pedagogiki wobec osób niepełnosprawnych, Wydawnictwo Uniwersytetu Marii Curie-Skłodowskiej, Lublin.

Jaranowska K. (1996), Osoby niepetnosprawne w środowisku miejskim, Wydawnictwo COBO-PROFIL, Warszawa.

Krause A. (2010), Wspótczesne paradygmaty pedagogiki specjalnej, Oficyna Wydawnicza „Impuls", Kraków.

Kuryłowicz E. (2005), Projektowanie uniwersalne. Sztokholm miasto dla wszystkich, Wydawnictwo Stowarzyszenie Przyjaciół Integracji, Warszawa.

Wapiennik E., Piotrowicz R. (2002), Niepetnosprawny - petnoprawny obywatel Europy, Wydawca: Urząd Komitetu Integracji Europejskiej, Warszawa.

Wysocki M. (2010), Projektowanie otoczenia dla osób niewidomych. Pozawzrokowa percepcja przestrzeni, Wydawnictwo Politechniki Gdańskiej, Gdańsk.

Budny J. (2004), Jak dostosować budynek, Wydawca: Stowarzyszenie Przyjaciół Integracji, Warszawa.

Szczupał B. (2013), Architektoniczne i urbanistyczne działania w kontekście potrzeb osób z niepetnosprawnością ruchowa - dylematy legislacyjne, Oficyna Wydawnicza „Impuls”, Kraków.
Akty prawne
Dz. U. z 2002 r. Nr 75, poz. 690, art. 94.
Dz. U. z 2002 r. Nr 75, poz. 690, art. 74. 